Article

\title{
Isolation and Purification of Potent Growth Inhibitors from Piper methysticum Root
}

\author{
Truong Mai Van, Tran Dang Xuan * (i), Truong Ngoc Minh ${ }^{(1)}$ and Nguyen Van Quan \\ Graduate school for International Development and Cooperation, Hiroshima University, Hiroshima 739-8529, \\ Japan; truongmaivan1991@gmail.com (T.M.V.); minhtn689@gmail.com (T.N.M.); \\ nguyenquan26@gmail.com (N.V.Q.) \\ * Correspondence: tdxuan@hiroshima-u.ac.jp; Tel./Fax: +81-82-424-6927
}

Received: 10 July 2018; Accepted: 28 July 2018; Published: 31 July 2018

\begin{abstract}
Piper methysticum (kava) root is known to possess promising weed suppressing activity. The present study was conducted to search for potent plant growth inhibitors from the root of this medicinal pepper plant. The ethyl acetate (EtOAc) extract exhibited the strongest reduction on growth of Raphanus sativus (radish) $\left(\mathrm{IC}_{50}\right.$ shoot and root growth $=172.00$ and $51.31 \mu \mathrm{g} / \mathrm{mL}$ respectively) among solvent extracts. From this active extract, nine potent growth inhibitors involved in the inhibitory activities of $P$. methysticum root were isolated, purified and characterized by column chromatography (CC), gas chromatography-mass spectrometry (GC-MS), electrospray ionization-mass spectrometry (ESI-MS) and nuclear magnetic resonance (NMR). The six fractions purified by CC included two flavanones: 5-hydroxy-4 ${ }^{\prime}, 7$-dimethoxyflavanone (C1) and 5,7-dihydroxy-4'-methoxy-6,8-dimethylflavanone (matteucinol, C2) and six kavalactones: 5,6-dehydro-kavain (C3), a mixture of kavain and yagonin (C4), yagonin (C5) and dihydro-5,6dehydrokavain, 7,8-dihydrokavain, dihydromethysticin and methysticin (C6). The amounts of 5-hydroxy-4',7-dimethoxyflavanone, matteucinol, 5,6-dehydrokavain and yangonin were 0.76, 2.50, 2.75 and $2.09 \mathrm{mg} / \mathrm{g}$ dry weight (DW), respectively. The two flavanones $\mathbf{C} 1$ and C2 exhibited the strongest inhibition on shoot elongation ( $\mathrm{IC}_{50}=120.22$ and $248.03 \mu \mathrm{g} / \mathrm{mL}$, respectively), whilst the two kavalactone mixtures $\mathbf{C} 4$ and $\mathbf{C} 6$ showed the highest suppression on root growth of $R$. sativus $\left(\mathrm{IC}_{50}=7.70\right.$ and $15.67 \mu \mathrm{g} / \mathrm{mL}$, respectively). This study was the first to report the purification and inhibitory activities of the two flavanones 5-hydroxy-4',7-dimethoxyflavanone and matteucinol in P. methysticum root. The isolated constituents from P. methysticum root including the flavanones $\mathbf{C 1}$ and $\mathbf{C} 2$ and the mixtures $\mathbf{C} 4$ and $\mathbf{C} 6$ may possess distinct modes of action on plant growth. Findings of this study highlighted that the combinations of hexane-ethyl acetate by 9:1 and 8:2 ratios successfully purified flavanones and kavalactones in P. methysticum root.
\end{abstract}

Keywords: Piper methysticum L.; Raphanus sativus; growth inhibitor; flavanone; kavalactone; natural herbicide

\section{Introduction}

Allelopathy is described as a phenomenon by which a plant possesses a natural ability to either inhibit or stimulate the growth of other plants in its vicinity by its biological toxins [1]. Taking advantages of this antagonistic plant-plant interaction, growth inhibitors from many plants have been examined for weed management. Since synthetic herbicides have negative impacts on environment and on human health, natural-based herbicide application is considered as an alternative tool to manage weeds in crop cultivation and establish a sustainable agriculture [2].

Piper methysticum G. Frost, belonging to the family Piperaceae, is a medical herb native to the South Pacific region [3]. The plant has long been reputed as an indispensable beverage for ceremonial and 
ritual purposes in Polynesia [3,4]. The consumption of Piper methysticum provides positive health effects, such as reduction of anxiety disorders, urinary tract infections and muscle relaxation $[5,6]$. Besides, root of $P$. methysticum which is commonly left after extraction showed promising inhibition on spontaneous growth of paddy weeds [7]. It was reported that extracts of P. methysticum root retard plant growth and possess potent allelochemicals [8-10]. Six kavalactones derived from P. methysticum root were purchased and examined for herbicidal and antifungal activities [9]. In addition, eight phenolic acids involved in inhibition against the harmful paddy weed Echinochloa crus-galli (barnyardgrass), were putatively identified and quantified by high performance-liquid chromatography (HPLC). Principal plant growth inhibitors of P. methysticum root belonged to the kavalactone group, which is differ chemically in their pyrone moieties [9]. In addition, whether the roots of P. methysticum contain effective growth inhibitors other than kavalactones and phenolic acids, requires further investigation.

This study carried out bioassay-guided trials of P. methysticum inhibition on growth of R. sativus according to different extracting solvents and fractions separated by column chromatography (CC). Gas chromatography-mass spectrometry (GC-MS), electrospray ionization-mass spectrometry (ESI-MS) and nuclear magnetic resonance $\left({ }^{1} \mathrm{H}\right.$ - and $\left.{ }^{13} \mathrm{C}-\mathrm{NMR}\right)$ were used to determine the chemical structures of isolated and bioactive constituents. The inhibitory levels of purified and identified compounds from P. methysticum root were also determined and characterized.

\section{Results}

\subsection{Inhibitory Effect of Different Extracts of P. methysticum Root}

Table 1 shows the inhibitory levels of extracts with solvents with different polarity (hexane, chloroform, ethyl acetate, acetone and water). It was found that all extracts exhibited some reduction of the elongations of shoot and root of R. sativus. In general, the strength of the inhibitory activities was proportional to the applied doses.

Table 1. Effect of different extracts of Piper methysticum root on growth of R. sativus.

\begin{tabular}{cccc}
\hline Extract & Concentration $(\boldsymbol{\mu g} / \mathbf{m L})$ & Shoot Inhibition (\%) & Root Inhibition (\%) \\
\hline \multirow{3}{*}{ Hexane } & 50 & $22.62 \pm 3.15^{\mathrm{d}}$ & $28.00 \pm 3.73^{\mathrm{i}}$ \\
& 250 & $55.33 \pm 3.06^{\mathrm{c}}$ & $70.54 \pm 3.82^{\mathrm{d}}$ \\
\hline \multirow{3}{*}{ Chloroform } & 500 & $68.67 \pm 3.06^{\mathrm{b}}$ & $89.52 \pm 3.36^{\mathrm{bc}}$ \\
& 50 & $25.40 \pm 2.75^{\mathrm{d}}$ & $36.67 \pm 3.51^{\mathrm{g}}$ \\
& 250 & $74.00 \pm 2.61^{\mathrm{ab}}$ & $88.48 \pm 3.94^{\mathrm{bc}}$ \\
EtOAc & 500 & $81.00 \pm 3.61^{\mathrm{a}}$ & $98.57 \pm 3.43^{\mathrm{a}}$ \\
\hline \multirow{3}{*}{ Acetone } & 50 & $24.79 \pm 3.39^{\mathrm{d}}$ & $39.33 \pm 3.76^{\mathrm{fg}}$ \\
& 250 & $78.33 \pm 2.08^{\mathrm{ab}}$ & $94.87 \pm 3.75^{\mathrm{ab}}$ \\
& 500 & $83.67 \pm 4.51^{\mathrm{a}}$ & $99.05 \pm 3.83^{\mathrm{a}}$ \\
\hline \multirow{3}{*}{ Water } & 50 & $24.13 \pm 4.29^{\mathrm{d}}$ & $36.11 \pm 3.47^{\mathrm{gh}}$ \\
& 250 & $78.67 \pm 3.12^{\mathrm{b}}$ & $85.62 \pm 2.72^{\mathrm{c}}$ \\
& 500 & $23.29 \pm 4.02^{\mathrm{d}}$ & $29.00 \pm 3.00^{\mathrm{ab}}$ \\
\hline
\end{tabular}

Values represent means \pm SD (standard deviation). Values in a column with different letters are significantly different $(p<0.05)$.

To compare the inhibitory levels among different solvent extracts, $\mathrm{IC}_{50}$ values were used. This represents the quantity of the extract needed to suppress $50 \%$ of the shoot and root growth of R. sativus. Therefore, a lower $\mathrm{IC}_{50}$ value indicates a stronger inhibitory activity. The results of inhibition on root and shoot length of $R$. sativus expressed as $\mathrm{IC}_{50}$ values are presented in Table 2. Among solvent extracts, the ethyl acetate (EtOAc) extract showed the highest inhibitory levels on root and shoot 
$\left(\mathrm{IC}_{50}=51.31\right.$ and $172.00 \mu \mathrm{g} / \mathrm{mL}$, respectively). Consequently, the suppressive strength could be ranked in the following order: EtOAc $>$ chloroform $>$ acetone $>$ hexane $>$ water. The greater inhibition of the EtOAc extract implied that it might contain more potent growth inhibitors than the other extracts, therefore, this fraction was selected for further analysis.

Table 2. Effect of P. methysticum root extracts on growth of $R$. sativus ( $\mathrm{IC}_{50}$ values).

\begin{tabular}{ccc}
\hline \multirow{2}{*}{ Extracts } & \multicolumn{2}{c}{ Inhibitory Levels, IC $_{50}(\boldsymbol{\mu g} / \mathrm{mL})$} \\
\cline { 2 - 3 } & Shoot & Root \\
\hline Hexane & $278.60 \pm 19.30^{\mathrm{b}}$ & $173.70 \pm 15.44^{\mathrm{b}}$ \\
Chloroform & $181.09 \pm 8.64^{\mathrm{c}}$ & $81.40 \pm 26.80^{\mathrm{c}}$ \\
Ethyl acetate & $172.00 \pm 25.20^{\mathrm{c}}$ & $51.31 \pm 0.23^{\mathrm{c}}$ \\
Acetone & $206.36 \pm 1.88^{\mathrm{bc}}$ & $90.50 \pm 21.00^{\mathrm{c}}$ \\
Water & $483.80 \pm 71.70^{\mathrm{a}}$ & $420.30 \pm 53.20^{\mathrm{a}}$ \\
\hline
\end{tabular}

Values represent means \pm SD (standard deviation); Values in a column with different letters are significantly different $(p<0.05)$.

\subsection{Isolation and Purification of Plant Growth Inhibitors by Column Chromatography}

Various combinations of solvents for column chromatography (CC) were examined, of which the mixture of hexane $(\mathrm{H})$ and ethyl acetate $(\mathrm{E})$ was the most effective to separate the constituents of the EtOAc extract (data not shown). Finally, the combinations of H:E at ratios 9:1 and 8:2 successfully separated six different fractions identified as C1-C6 (Table 3).

Table 3. Fractions isolated from Piper methysticum root by column chromatography.

\begin{tabular}{ccc}
\hline Fraction & Solvent Combination and Fraction & Weight (mg) \\
\hline C1 & Crystal in H-E 9:1 (fractions 14-17) & 7.7 \\
C2 & Crystal in H-E 9:1 (fractions 20-26) & 54.7 \\
C3 & Crystal in H-E 8:2 (fractions 11-15) & 174.4 \\
C4 & Crystal in H-E 8:2 (fractions 32-47) & 518.0 \\
C5 & Crystal in H-E 8:2 (fractions 48-55) & 70.3 \\
C6 & Crystal in H-E 8:2 (fractions 69-74) & 49.0 \\
\hline
\end{tabular}

$\mathrm{H}$ : hexane; E: ethyl acetate.

Next, the fractions were characterized by GC-MS, ESI-MS and ${ }^{1} \mathrm{H}$ - and ${ }^{13} \mathrm{C}-\mathrm{NMR}$ to identify their chemical components. From $165.9 \mathrm{~g}$ powder Piper methysticum root, a total of $6.5 \mathrm{~g}$ of EtOAc extract was isolated and fractionated by CC (Table 4$)$ into the following fractions: 5,6-dehydrokavain (174.4 mg, C3), yangonin (70.3 mg, C5), 5-hydroxy-4',7-dimethoxyflavanone (7.7 mg, C1) and matteucinol (54.7 mg, C2) (Tables 3 and 4). The other two solids were mixtures of kavain (59.42\%) and yagonin (40.58\%) (C4) and dihydro-5,6-dehydrokavain (12.78\%), 7,8-dihydrokavain (20.44\%), dihydromethysticin (54.77\%) and methysticin (8.90\%) (C6, Table 4). The chemical structures of these compounds were elucidated based on their spectroscopic data (Figure 1, Table 4) (Supplementary data, Figures S1-S24). The mixture C4 afforded the highest yield $(518.0 \mathrm{mg})$, whereas the fraction $\mathbf{C} 1$ provided the minimum amount (7.7 mg) among all fractions. 
Table 4. Identification of bioactive compounds from EtOAc extract of P. methysticum root by GC-MS, ESI-MS and ${ }^{1} \mathrm{H}$ - and ${ }^{13} \mathrm{C}-\mathrm{NMR}$.

\begin{tabular}{ccccccc}
\hline Fraction & $\begin{array}{c}\text { Retention } \\
\text { Time }\end{array}$ & $\begin{array}{c}\text { Peak } \\
\text { Area (\%) }\end{array}$ & Compounds & $\begin{array}{c}\text { Chemical } \\
\text { Formula }\end{array}$ & $\begin{array}{c}\text { Molecular } \\
\text { Weight }\end{array}$ & $\begin{array}{c}\text { Chemical } \\
\text { Class }\end{array}$ \\
\hline $\mathbf{C} \mathbf{1}$ & 23.40 & 93.28 & 5-Hydroxy-4',7-dimethoxyflavanone & $\mathrm{C}_{17} \mathrm{H}_{16} \mathrm{O}_{5}$ & 300 & Flavanone \\
\hline $\mathbf{C} \mathbf{2}$ & 25.37 & 90.00 & Matteucinol & $\mathrm{C}_{18} \mathrm{H}_{18} \mathrm{O}_{5}$ & 314 & Flavanone \\
\hline $\mathbf{C} \mathbf{3}$ & 20.80 & 94.66 & 5,6-Dehydrokavain (DK) & $\mathrm{C}_{14} \mathrm{H}_{12} \mathrm{O}_{3}$ & 228 & Kavalactone \\
\hline \multirow{2}{*}{$\mathbf{C} 4$} & 20.07 & 59.42 & Kavain & $\mathrm{C}_{14} \mathrm{H}_{14} \mathrm{O}_{3}$ & 230 & Kavalactone \\
& 23.37 & 40.58 & Yangonin & $\mathrm{C}_{15} \mathrm{H}_{14} \mathrm{O}_{4}$ & 258 & Kavalactone \\
\hline $\mathbf{C 5}$ & 23.34 & 93.64 & Yangonin & $\mathrm{C}_{15} \mathrm{H}_{14} \mathrm{O}_{4}$ & 258 & Kavalactone \\
\hline & 16.25 & 12.78 & Dihydro-5,6-dehydrokavain (DDK) & $\mathrm{C}_{14} \mathrm{H}_{14} \mathrm{O}_{3}$ & 230 & Kavalactone \\
$\mathbf{C 6}$ & 18.35 & 20.44 & 7,8-Dihydrokavain & $\mathrm{C}_{14} \mathrm{H}_{16} \mathrm{O}_{3}$ & 232 & Kavalactone \\
& 22.45 & 54.77 & Dihydromethysticin & $\mathrm{C}_{15} \mathrm{H}_{16} \mathrm{O}_{5}$ & 276 & Kavalactone \\
& 23.40 & 8.90 & Methysticin & $\mathrm{C}_{15} \mathrm{H}_{14} \mathrm{O}_{5}$ & 274 & Kavalactone \\
\hline
\end{tabular}

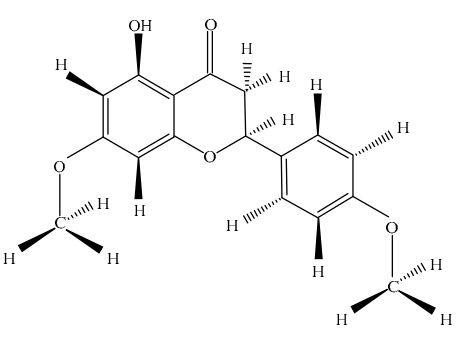

5-Hydroxy-4',7-

dimethoxyflavanone (C1)

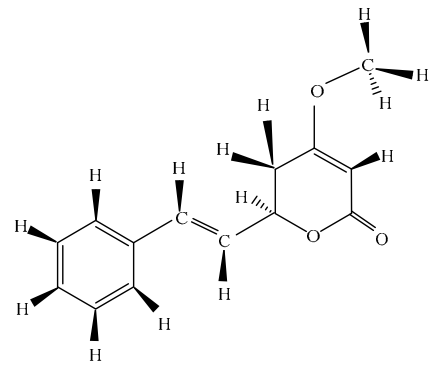

Kavain (C4)

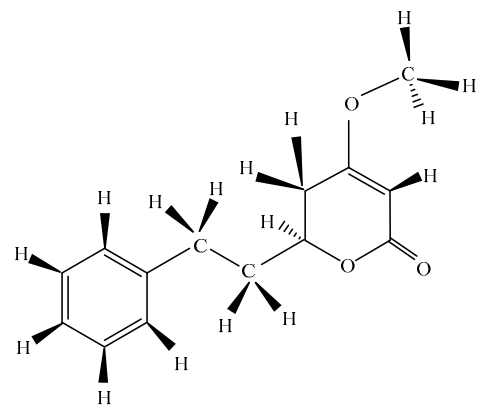

7,8-Dihydrokavain (C6)

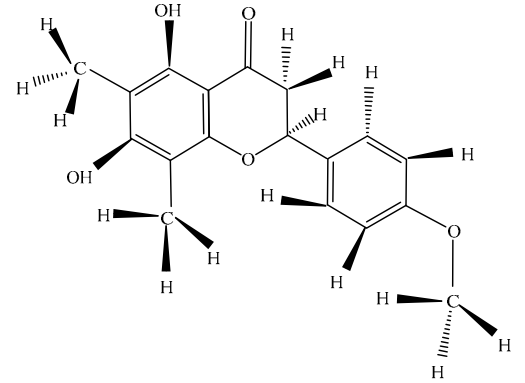

Matteucinol (C2)

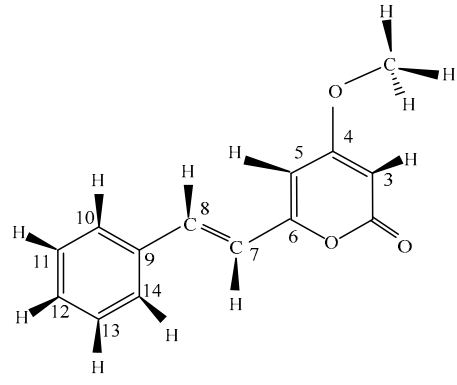

5,6-Dehydrokavain (DK) (C3)

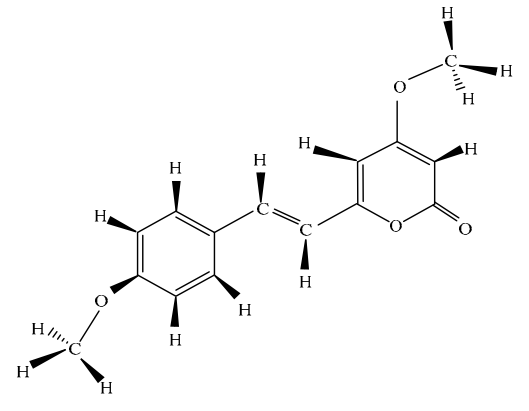

Yangonin (C4, C5)

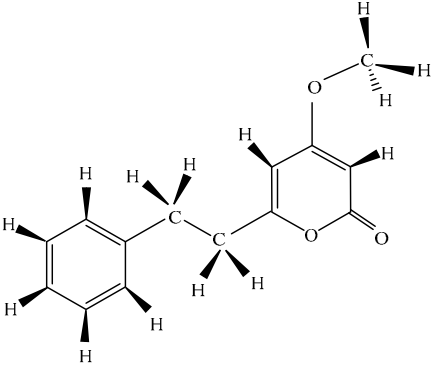

Dihydro-5,6-dehydrokavain (DDK) (C6)

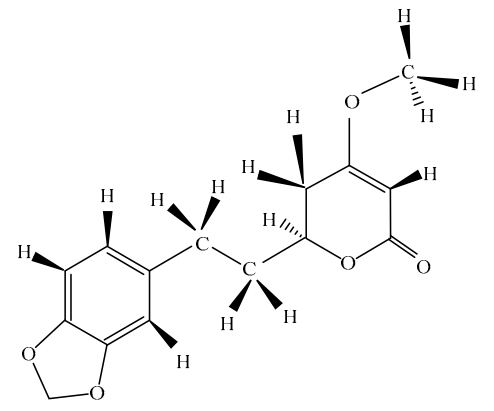

Dihydromethysticin (C6)

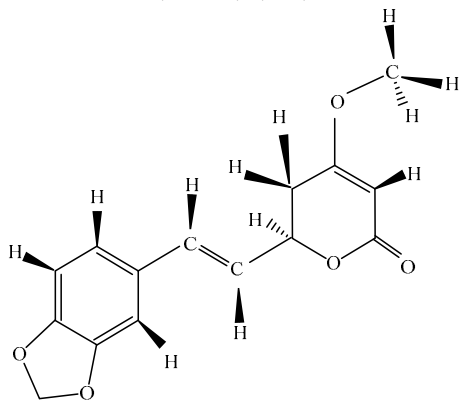

Methysticin (C6)

Figure 1. Chemical structures of bioactive constituents from P. methysticum root. 


\subsection{Quantitative Analysis of Bioactive Compounds from P. methysticum Root}

Because the four compounds 5-hydroxy-4',7-dimethoxyflavanone, matteucinol, 5,6-dehydrokavain and yangonin were purified, they were used as the standards to quantify their contents in P. methysticum root by GC-MS (Table 5). Of them, 5,6-dehydrokavain (DK) was the predominant component (2.75 mg/g DW), followed by matteucinol (2.50 mg/g DW) and yangonin (2.09 mg/g DW). The content of 5-hydroxy-4', 7 -dimethoxyflavanone was minimum $(0.76 \mathrm{mg} / \mathrm{g} \mathrm{DW})$.

Table 5. Quantity of purified compounds from P. methysticum root.

\begin{tabular}{cccc}
\hline Fractions & Retention Time & Compounds & mg/g DW \\
\hline C1 & $23.38 \pm 0.01$ & 5-Hydroxy- $4^{\prime}, 7$-dimethoxyflavanone & 0.76 \\
C2 & $25.36 \pm 0.02$ & Matteucinol & 2.50 \\
C3 & $20.65 \pm 0.01$ & 5,6-Dehydrokavain & 2.75 \\
C5 & $23.34 \pm 0.01$ & Yangonin & 2.09 \\
\hline
\end{tabular}

DW: dry weight.

\subsection{Inhibitory Activity of the Isolated Compounds on the Growth of R. sativus}

Table 6 showed that all isolated constituents from P. methysticum reduced elongation of R. sativus, although the levels of inhibition varied among compounds, their mixtures, shoot and root of radish. Among the four purified compounds, both of the two flavanones $(\mathbf{C 1}, \mathbf{C 2})\left(\mathrm{IC}_{50}=120.22,248.03 \mu \mathrm{g} / \mathrm{mL}\right.$, respectively) exhibited much higher inhibitory activities on shoot elongation of $R$. sativus than the two lactones $\left(\mathbf{C} 3, \mathbf{C 5}, \mathrm{IC}_{50}=265.88,313.82 \mu \mathrm{g} / \mathrm{mL}\right.$, respectively). The mixtures $\mathbf{C 4}$ and $\mathbf{C 6}$ showed excellent suppression on root growth $\left(\mathrm{IC}_{50}=7.70,15.67 \mu \mathrm{g} / \mathrm{mL}\right.$, respectively), as compared to C3 and C5 (Table 6). The inhibitory magnitudes of $\mathbf{C 4}$ and $\mathbf{C 6}$ on root growth of $R$. sativus were much stronger than shoot elongation of other kavalactones as well as their mixtures and the two flavanones. The findings in Table 6 suggest that the mixtures of $\mathbf{C} 4$ and $\mathbf{C 6}$ may possess a novel mode of inhibitory action on plant root elongation. However, further trials on the effects of individual compounds in $\mathbf{C 4}$ and $\mathbf{C 6}$ on root growth of different indicator plants including weeds should be performed.

Table 6. Inhibitory activity of isolated compounds from P. methysticum root on growth of $R$. sativus ( $\mathrm{IC}_{50}$ values).

\begin{tabular}{cccc}
\hline \multirow{2}{*}{ Fractions } & Compounds & \multicolumn{2}{c}{ IC $_{50}(\mu \mathrm{g} / \mathrm{mL})$} \\
\cline { 3 - 4 } & & Shoot & Root \\
\hline C1 & 5-Hydroxy-4',7-dimethoxyflavanone & $120.22 \pm 14.64^{\mathrm{e}}$ & - \\
C2 & Matteucinol & $248.03 \pm 5.43^{\mathrm{d}}$ & - \\
C3 & 5,6-Dehydrokavain (DK) & $265.88 \pm 19.78^{\mathrm{c}, \mathrm{d}}$ & $375.33 \pm 11.93^{\mathrm{a}}$ \\
C4 & Kavain; yangonin & $457.18 \pm 28.64^{\mathrm{a}}$ & $7.70 \pm 1.57^{\mathrm{b}}$ \\
C5 & Yangonin & $313.82 \pm 0.68^{\mathrm{b}, \mathrm{c}}$ & $365.00 \pm 44.00^{\mathrm{a}}$ \\
C6 & Dihydro-5,6-dehydrokavain (DDK); & $360.19 \pm 20.37^{\mathrm{b}}$ & $15.67 \pm 5.13^{\mathrm{b}}$ \\
\hline
\end{tabular}

Values represent means $\pm \mathrm{SD}$ (standard deviation). -: measurements were not conducted. Values in a column with different letters are significantly different $(p<0.05)$.

\section{Discussion}

In our previous research, eight phenolic compounds including gallic acid, protocatechuic acid, $p$-hydroxybenzoic acid, $p$-coumaric acid, ferulic acid, salicylic acid, trans-o-coumaric acid and trans-cinamic acid potentially involved in the weed suppressing ability of $P$. methysticum root were identified by high performance-liquid chromatography (HPLC) and thin layer chromatography (TLC) analyses [8]. The most phytotoxic spot visible from TLC reduced the shoot and root elongation of Echinochloa crus-galli (barnyard grass) by $80 \%$ and $95 \%$, respectively. However, the isolation and 
purification of plant growth inhibitors other than phenolic acids were not achieved [8]. In another trial, six kavalactones, including methysticin, 7,8-dihydrokavain, 5,6-dehydrokavain, kavain, yangonin, dihydromethysticin were purchased and examined for their inhibitory activities against Lactuca sativa (lettuce), barnyard grass and some harmful fungi [9]. Dihydromethysticin was the most potential as it inhibited growth of lettuce by $80.4 \%$ by $10 \mu \mathrm{g} / \mathrm{mL}$, whilst methysticin was the best at reducing barnyard grass emergence (by 66.6\%) [9]. Although the efficacy of different extraction solvents on the chemical components in P. methysticum root was examined [11], the presence of the different constituents was analysed by only GC-MS [11]. Several attempts on isolation and purification of bioactive constituents have been carried out, but principally related to the medicinal and pharmaceutical properties of kavalactones, using HPLC, GC-MS and common analytical instruments [12-17]. Protocols for successfully isolating and purifying bioactive kavalactones as well as bioactive chemicals in P. methysticum root have not yet been reported.

The present study investigated the inhibitory effects of different solvent extracts of P. methysticum root on the growth of $R$. sativus. It was observed that levels of inhibition on root length were higher than on shoot elongation (Table 2). The phytotoxic effect on plant growth is dependent on the composition and concentration of growth inhibitors [18]. Secondary metabolites from plants including terpenoids, steroids, phenols, coumarins, alkaloids and flavonoids have been documented as allelochemicals [19]. Plant growth inhibitors or allelochemicals inhibit growth of neighboring plants by disturbing their physiological processes such as photosynthesis, respiration, water and hormonal balance [20]. The application of extraction solvents with different polarities is crucial to isolate and purify bioactive compounds in plants [21]. However, many natural products have complicated chemical structures, making their purification processes therefore sophisticated, laborious and time-consuming [22]. The pharmacological properties of P. methysticum beverages have attracted many researchers over the past 130 years in order to exploit the biologically active constituents $[3,23]$. To date, more than 40 compounds have been identified from P. methysticum root [24], predominantly belonging to kavalactones, chalcones and flavones and conjugated diene ketones [24], of which, kavalactones accounted for approximately $96 \%$ of the lipid extract and 3-20\% by dry weight [24-26]. However, it was reported that chemotype and kavalactone contents in P. methysticum root were controlled by the plant organ, genetics and environmental factors [27].

This study found that among solvent extracts, the EtOAc one exhibited the maximal inhibitory effect on the growth of R. sativus, as compared to those of chloroform, acetone and hexane (Table 3). Li et al. [28] documented that suitable solvents achieved high yields of potential allelochemicals. Only seven kavalactones, including 5,6-dehydrokavain, kavain, yangonin, dihydro-5,6dehydrokavain, 7,8-dihydrokavain, dihydromethysticin and methysticin were identified and quantified (Tables 4 and 5), although a total of 18 kavalactones are known to be found in P. methysticum root [11]. The other known kavalactones were absent, thus suggested that they might correlate to much weaker inhibitory activity and be found in other extracts such as hexane, chloroform and water (Tables 1 and 2). Among the identified constituents, though the flavanones $\mathbf{C} 1$ and $\mathbf{C} 2$ and the individual kavalactones $\mathbf{C} 3$ and $\mathbf{C} 5$ showed stronger inhibition, the mixtures of kavalactones in $\mathbf{C} 4$ and C6 were the most potent, as they inhibited root elongation of $R$. sativus by $\mathrm{IC}_{50}=7.70$ and $15.67 \mu \mathrm{g} / \mathrm{mL}$, respectively (Table 6). The modes of action of the mixtures $\mathbf{C 4}$ and $\mathbf{C 6}$ on different indicator plants including weeds should be further investigated to examine whether they are actually potent enough for the development of novel herbicides.

In this research, the flavanone $\mathbf{C} \mathbf{1}$ was previously identified by GC-MS [9] and the flavanone C2 matteucinol was detected for the first time in P. methysticum root. This research successfully purified and quantified the two compounds and reported their stronger inhibitory activities than those of other kavalactones on growth of $R$. sativus (Table 6). Compound C1 (5-hydroxy-4',7-dimethoxyflavanone) was reported as an antifungal and antioxidant substance in Argentinean propolis and some other herbal plants such as Piper caninum and Combretum zeyheri [29-31], while no information about biological activities of matteucinol was documented. To date, the mechanisms of flavanones other 
than allelopathy remain vague. It might be that their interference induces cell growth inhibition, ATP production disturbances and hinders the proper functioning of auxins [32].

The findings in Table 3 indicated that the combination of hexane-ethyl acetate at 9:1 and 8:2 ratios successfully yielded the pure flavanones $\mathbf{C} 1$ and $\mathbf{C} 2$ and kavalactones (C3, C5 and mixtures of $\mathbf{C} 4$ and C6). The mixture of kavain and yangonin in $\mathrm{C} 4$ and four kavalactones including dihydro-5,6-dehydrokavain, 7,8-dihydrokavain, dihydromethysticin and methysticin in C6 needed further purification by CC with a more effective combination of solvents. As P. methysticum is a Pacific herbal remedy which is highly recommended as a treatment for diseases related to nervous disorders such as anxiety, insomnia and stress [33], although the consumption of kava-containing products has been suspected of causing liver damage in a few cases [34-37]. In contrast, P. methysticum was also reported to be non-toxic to the liver, and it may even possess liver protective properties [38,39]. The protocols for purification of bioactive chemicals in P. methysticum root including flavanones and kavalactones developed by this study should prove useful to exploit more effectively the biological activities of this tropical herb. Alpinia zerumbet which also possesses kavalactones including DK and DDK [12,40-43] may be utilized these protocols to isolate potent flavanones and other kavalactones from this medicinal plant. The consumption of $A$. zerumbet as a dietary supplement which includes the bioactive constituents DK and DDK by Okinawans was recorded in a study of the longevity of Japanese people living in islands of the Ryukyus [44]. As DK and DDK are the two kavalactones [9,11,40-44], whether the use of P. methysticum root as a traditional beverage contributes to the health and longevity of Polynesian and Pacific islanders needs further investigation.

\section{Materials and Methods}

\subsection{Plant Materials}

\subsubsection{Piper methysticum Root}

Commercial dried P. methysticum root was purchased from Kava King Products, Inc. (Ormond Beach, FL, USA) on 2 May 2017. The root powder was stored in the freezer at the temperature of $-20{ }^{\circ} \mathrm{C}$ prior to extraction.

\subsubsection{Tested Plants}

Seeds of R. sativus were purchased from Taki Co. Ltd. (Kyoto, Japan). Empty and unhealthy seeds were removed by floating in tap water. After air-drying, the selected seeds were treated with $0.1 \%$ sodium hypochlorite for $30 \mathrm{~min}$ and then washed by sterile water in triplicate.

\subsection{Preparation of Plant Extract}

Dried Piper methysticum root powder (907.2 g) was extracted with $3 \mathrm{~L}$ of acetone solvent for 2 week at room temperature. After filtration using filter paper (Whatman No.5C, $110 \mathrm{~mm}$ ), the residue was evaporated to dryness by a rotary evaporator (SB-350, EYELA, Tokyo, Japan) at $45{ }^{\circ} \mathrm{C}$ and yielded $49.39 \mathrm{~g}$ of crude acetone extract. An amount of $1.5 \mathrm{~g}$ the acetone crude extract was dissolved with methanol $(\mathrm{MeOH})$ to enhance the solubility in bioassays and different dilutions $(50,250$ and $500 \mu \mathrm{g} / \mathrm{mL}$ ) were thus obtained. The remaining acetone crude extract $(47.89 \mathrm{~g}$ ) was dissolved in $100 \mathrm{~mL}$ distilled water and fractionated subsequently with hexane, chloroform and ethyl acetate. This resulted in $0.42 \mathrm{~g}$ of hexane ( $0.9 \%), 46.86 \mathrm{~g}$ of chloroform $(99.94 \%), 2.6 \mathrm{~g}$ of EtOAc $(5.54 \%)$ and $0.34 \mathrm{~g}$ of water $(0.73 \%)$ extracts. All extracts were temporarily stored at $-5{ }^{\circ} \mathrm{C}$ in the dark before the bioassays.

\subsection{Inhibitory Activity of P. methysticum Root Crude Extracts}

Inhibitory assays were performed to measure the effects of various concentrations of P. methysticum root extract on R. sativus growth inhibition. Three dilutions $(50,250$ and $500 \mu \mathrm{g} / \mathrm{mL}$ ) of each crude extract were prepared for this study. After that, each ten surface-sterilized seeds were placed in a 
Petri dish lined with a filter paper moistened with $200 \mathrm{~mL}$ of each tested solution. Water was used as a control. Treatments were designed randomly with three replicates. The $R$. sativus seed growth was observed under a condition of $25 / 23{ }^{\circ} \mathrm{C}$ temperature over photoperiod $12 / 12 \mathrm{~h}$ day/night inside a growth chamber (Biotron NC system, Nippon Medical \& Chemical Instrument, Co. Ltd., Osaka, Japan). After 5 days, root length and shoot height were recorded to determine the inhibitory levels on of seedling growth and expressed by $\mathrm{IC}_{50}$ values. The extract showed the strongest inhibition on the germination and growth of $R$. sativus was further fractionated.

\subsection{Isolation and Purification of Bioactive Compounds}

\subsubsection{General Experimental Procedures}

Column chromatography (20 mm diameter $\times 500 \mathrm{~mm}$ height, Climbing G2, Tokyo, Japan) was performed using silica gel (size Á 60, 200-400 mesh particle size, Sigma-Aldrich, Tokyo, Japan). Thin layer chromatography (TLC) was conducted by TLC plates with layer thickness was $0.25 \mathrm{~mm}$. The TLC spots were observed by spraying with EtOAc: $\mathrm{H}_{2} \mathrm{SO}_{4}(95: 5)$ followed by heating at $100{ }^{\circ} \mathrm{C}$ in an oven (Laboratory Convection Oven MOV-212F D, SANYO, Gunma, Japan) for 3 min. GC-MS analysis was run on a JMS-T100 GCV system (JEOL Ltd., Tokyo, Japan). The compound identification was carried out by comparing the mass spectral fragmentation patterns of the samples with the mass spectral libraries of JEOL's GC-MS Mass Center System Version 2.65a software. The electrospray ionization-mass spectrometry (ESI-MS) experiments were performed in a LTQ Orbitrap XL mass spectrometer (Thermo Scientific, Bremen, Germany). The nuclear magnetic resonance spectra ( ${ }^{1} \mathrm{H}-\mathrm{NMR}$ at $400.13 \mathrm{~Hz}$ and ${ }^{13} \mathrm{C}-\mathrm{NMR}$ at $100.612 \mathrm{~Hz}$ ) were recorded with a model 500 spectrometer (Bruker Yokohama, Japan) with samples dissolved in $\mathrm{CDCl}_{3}$.

\subsubsection{Isolation, Purification and Identification by CC, GC-MS, EIS-MS, ${ }^{1} \mathrm{H}$ - and ${ }^{13} \mathrm{C}-\mathrm{NMR}$}

Dried powder of Piper methysticum root $(165.9 \mathrm{~g})$ was extracted with a solvent system of acetone-acetonitrile (4:1) for one week at room temperature. The extract was then filtered and dried under reduced pressure using a rotary evaporator at $45^{\circ} \mathrm{C}$. The obtained crude extract (9.4 g) was suspended in distilled water and partitioned in a separatory funnel with hexane $(\mathrm{H})$ and EtOAc (E). The most active EtOAc extract was evaporated to yield $6.5 \mathrm{~g}$ of crude extract. After thin layer chromatography (TLC) analysis, the EtOAc extract was chromatographed on a column (20 mm diameter $\times 500 \mathrm{~mm}$ height, Climbing G2, Tokyo, Japan) over silica gel (size Á 60, 200-400 mesh particle size, Sigma-Aldrich, Tokyo, Japan). The elution was conducted using sequential solvent systems of increasing polarity ( $n$-hexane-EtOAc 10:0-0:10 v/v), followed by $\mathrm{MeOH} \mathrm{100 \% .} \mathrm{Similar} \mathrm{fractions} \mathrm{(frs.;}$ each of $100 \mathrm{~mL}$ ) as observed by TLC were pooled together and concentrated to dryness using a rotary evaporator. Six fractions crystallized at room temperature, of which, four were pure compounds and other were mixtures. All isolated compounds and the mixtures were analysed and confirmed by GC-MS and ESI-MS, ${ }^{1} \mathrm{H}-\mathrm{NMR}$ and ${ }^{13} \mathrm{C}-\mathrm{NMR}$ to determine their chemical structures.

5-Hydroxy-4',7-dimethoxyflavanone (C1). Compound C1 was isolated as a white powder from the combined fractions 14-17, which were eluted with 9:1 H-E. This compound was purified after eluting by hexane and filtering through a filter paper to remove contaminants. The purity of the substance was determined to be $93.28 \%$ by GC-MS analysis (Supplementary Material, Figure S1). Its molecular formula was identified to be $\mathrm{C}_{17} \mathrm{H}_{16} \mathrm{O}_{5}$ based on ESI-MS: $m / z 301.1[\mathrm{M}-\mathrm{H}]^{+}$(Supplementary Material, Figure S2). The identification as 5-hydroxy-4',7-dimethoxyflavanone (Figure 1) was obtained by analysis of its ${ }^{1} \mathrm{H}$ - and ${ }^{13} \mathrm{C}-\mathrm{NMR}$ spectra and literature data [34]. ${ }^{1} \mathrm{H}-\mathrm{NMR} \delta$ (ppm): $12.8(1 \mathrm{H}, \mathrm{s}) ; 7.78$ $\left(2 \mathrm{H}, \mathrm{dd}, 8 \mathrm{~Hz}, 4 \mathrm{~Hz}, \mathrm{H} 2^{\prime}\right.$ and H6 $) ; 6.97$ (2H, dd, $8 \mathrm{~Hz}, 4 \mathrm{~Hz}, \mathrm{H}^{\prime}$ and H5'); 6.52 (1H, s, H3); 6.43 (1H, d, $4 \mathrm{~Hz}, \mathrm{H} 8) ; 6.32$ (1H, d, $4 \mathrm{~Hz}, \mathrm{H} 6) ; 3.86(3 \mathrm{H}, \mathrm{s}) ; 3.85(3 \mathrm{H}, \mathrm{s}) .{ }^{13} \mathrm{C}-\mathrm{NMR} \delta$ (ppm): 163.9 (C2), 104.2 (C3), 182.4 (C4), 162.0 (C5), 98.0 (C6), 165.3 (C7), 92.5 (C8), 157.6 (C9), 105.4 (C10), $123.4\left(\right.$ C1 $\left.^{\prime}\right), 127.9$ (C2'), 
$114.4\left(\mathrm{C} 3^{\prime}\right), 162.5\left(\mathrm{C}^{\prime}\right), 114.4\left(\mathrm{C5}^{\prime}\right), 127.9\left(\mathrm{C}^{\prime}\right), 55.8$ (C6'-OCH3), 55.5(C7-OCH3). (Supplementary Material, Figures S3 and S4).

5,7-Dihydroxy-4'-methoxy-6,8-dimethylflavanone (C2). Compound C2 was precipitated as a yellow powder from fractions 20-26 which were eluted with 9:1 H-E. Hexane was used to purify this compound. The molecular formula of compound $\mathrm{C} 2$ was identified as $\mathrm{C}_{18} \mathrm{H}_{18} \mathrm{O}_{5}$ based on ESI-MS: $m / z 314.12[\mathrm{M}-\mathrm{H}]^{+}$while the purity was 90\% using GC-MS analysis (Supplementary Material, Figure S6). The identification as 5,7-dihydroxy-4'-methoxy-6,8-dimethylflavanone or matteucinol (Figure 1) was obtained by analysis of its ${ }^{1} \mathrm{H}$ - and ${ }^{13} \mathrm{C}-\mathrm{NMR}$ spectra and literature data [45]. ${ }^{1} \mathrm{H}-\mathrm{NMR} \delta(\mathrm{ppm})$ : 2.03(3H, s, 6-CH3), $2.05(3 \mathrm{H}, \mathrm{s}, 8-\mathrm{CH} 3), 2.78(1 \mathrm{H}, \mathrm{dd}, J=17 \mathrm{~Hz}, 3 \mathrm{~Hz}, \mathrm{H}-3 \beta), 3.03(1 \mathrm{H}, \mathrm{dd}, J=17 \mathrm{~Hz}$, $13 \mathrm{~Hz}, \mathrm{H}-3 \alpha), 3.83(3 \mathrm{H}, \mathrm{s}, \mathrm{OCH} 3), 5.32(1 \mathrm{H}, \mathrm{dd}, J=13 \mathrm{~Hz}, 3 \mathrm{~Hz}, \mathrm{H}-2), 6.95\left(2 \mathrm{H}, \mathrm{d}, J=9 \mathrm{~Hz}, \mathrm{H}-3^{\prime}, 5^{\prime}\right), 7.39$ $\left(2 \mathrm{H}, \mathrm{d}, J=9 \mathrm{~Hz}, \mathrm{H}-2^{\prime}, 6^{\prime}\right), 12.29\left(1 \mathrm{H}, \mathrm{s}\right.$, chelated 5-OH). ${ }^{13} \mathrm{C}-\mathrm{NMR} \delta$ (ppm): 6.9 (6-CH3), $7.6(8-\mathrm{CH} 3), 43.1$ $(3 \alpha, 3 \beta), 55.2$ (OCH3), 78.2 (C-1), 102.3 (C-8), 102.7 (C-10), 103.5 (C-6), $114.0\left(\mathrm{C}-3^{\prime}, 5^{\prime}\right), 127.4\left(\mathrm{C}-2^{\prime}, 6^{\prime}\right)$, $131.0\left(\mathrm{C}-1^{\prime}\right), 157.7$ (C-9), 158.8 (C-5), 159.6 (C-4'), 162.1 (C-7), 196.5 (C-4) (Supplementary Material, Figures S6-S12).

5,6-Dehydrokavain (C3). Compound C3 was isolated as pale-yellow needles from fractions 11-15 which were eluted with 8:2 H-E. Hexane was also used to purify this compound with the purity being evaluated as $94.66 \%$ by GC-MS (Supplementary Material, Figure S13). According to ESI-MS data $(m / z$ : $229.1[\mathrm{M}-\mathrm{H}]^{+}$, Supplementary Material, Figure S14), the molecular formula of compound C3 was determined as $\mathrm{C}_{14} \mathrm{H}_{14} \mathrm{O}_{3}$. The ${ }^{1} \mathrm{H}$ - and ${ }^{13} \mathrm{C}$-NMR results were interpreted to match 5,6-dehydrokavain (Figure 1) by compared with spectroscopic data in the literature [12]. ESI-MS: $229.1\left[\mathrm{M}+\mathrm{H}^{+}{ }^{+}{ }^{1} \mathrm{H}-\mathrm{NMR}\right.$ $\delta$ (ppm): 3.87 (3H, s, MeO-), $5.62(1 \mathrm{H}, \mathrm{d} ; J=2.2 \mathrm{~Hz}, 3-\mathrm{H}), 6.24\left({ }^{1} \mathrm{H}, \mathrm{d} ; J=2.2 \mathrm{~Hz}, 5-\mathrm{H}\right), 6.86(1 \mathrm{H}, \mathrm{d}$; $J=16 \mathrm{~Hz}, 7-\mathrm{H}), 7.43(1 \mathrm{H}, \mathrm{d} ; J=16 \mathrm{~Hz}, 8-\mathrm{H}), 7.36-7.59\left(5 \mathrm{H}, \mathrm{m}\right.$, aromatic); ${ }^{13} \mathrm{C}-\mathrm{NMR}(\delta(\mathrm{ppm}): 56.61$ (MeO-), 89.50 (C-3), 102.73 (C-5), 120,12 (C-7), 128.10 (C-14), 128,44 (C-10), 129,41 (C-13), 129.52 (C-11), 130.23 (C-12), 136.31 (C-9), 136.74 (C-8), 160.55 (C-2), 166.63 (C-6), 173.34 (C-4) (Supplementary Material, Figures S15 and S16).

Yangonin (C5). Fractions 48-55 were eluted with a solvent system of 8:2 H-E to yield $70.3 \mathrm{mg}$ of yangonin (as light yellow needles). Its molecular formula was established to be $\mathrm{C}_{15} \mathrm{H}_{14} \mathrm{O}_{4}$ on the basis of ESI-MS: $m / z 259.1[\mathrm{M}-\mathrm{H}]^{+}$(Supplementary Material, Figure S20). The combined fractions were eluted with a 6:4 H-E solvent mixture to obtain the pure compound. The purity of yangonin reached $93.64 \%$ according to GC-MS result (Supplementary Material, Figure S19). The compound was identified as yangonin (Figure 1) by comparison between its ${ }^{1} \mathrm{H}$ - and ${ }^{13} \mathrm{C}-\mathrm{NMR}$ spectra with the spectroscopic data reported in the literature [46]. ${ }^{1} \mathrm{H}-\mathrm{NMR} \delta(\mathrm{ppm}): 5.45(\mathrm{~d}, J=2.1 \mathrm{~Hz}, \mathrm{H}-3) ; 5.87$ $(\mathrm{d}, J=2.1 \mathrm{~Hz}, \mathrm{H}-5) ; 6.43$ (d, $J=16.0 \mathrm{~Hz}, \mathrm{H}-7) ; 7.43$ (d, $J=16.0 \mathrm{~Hz}, \mathrm{H}-8) ; 7.42$ (d, $J=8.8 \mathrm{~Hz}, \mathrm{H}-10$ and $\mathrm{H}-14) ; 6.88$ (d, J = 8.8 Hz, H-11 and H-13); 3.82 (s, 4-OMe); 3.79 (s, 12-OMe). ${ }^{13} \mathrm{C}-\mathrm{NMR} \delta$ (ppm): 164.1 (C-2), 88.3 (C-3), 171.2 (C-4), 100.4 (C-5), 159.0 (C-6), 116.3 (C-7), 135.4 (C-8), 127.9 (C-9), 1289 (C-10), 114.3 (C-11), 160.7 (C-12), 114.3 (C-13), 128.9 (C-14), 55.8 (4-OMe), 55.3 (12-OMe) (Supplementary Material, Figures S21 and S22).

\subsubsection{Chemical Identification and Quantification}

\section{GC-MS Analysis}

To elucidate the name, structure and chemical properties of the identified constituents, GC-MS analysis was performed. One $\mu \mathrm{L}$ aliquot of each compound was diluted in chloroform to obtain 1000 $\mu \mathrm{g} / \mathrm{mL}$ concentration. After that, the solvents were injected into the GC-MS system equipped with a DB-5MS capillary column, $30 \mathrm{~m}$ in length, $0.25 \mathrm{~mm}$ internal diameter and $0.25 \mu \mathrm{m}$ in thickness (Agilent Technologies, J \& W Scientific Products, Folsom, CA, USA). The data were recorded using helium as carrier gas. At the beginning of the program, the GC oven temperature program was set up at $50{ }^{\circ} \mathrm{C}$ without any hold time, then increased to $300^{\circ} \mathrm{C}$ at a rate of $10^{\circ} \mathrm{C} / \mathrm{min}$ and finally held for $30 \mathrm{~min}$ at $300^{\circ} \mathrm{C}$. The injector and detector temperature were set at $300^{\circ} \mathrm{C}$ and $320^{\circ} \mathrm{C}$, respectively, with a mass 
scan range from 29 to $800 \mathrm{amu}$. The compound identification was carried out by comparing the mass spectral fragmentation patterns of the samples with the mass spectral libraries of JEOL's GC-MS Mass Center System Version 2.65a and standards.

Quantification of Growth Inhibitors of P. methysticum Root

Four pure compounds C1, C2, C3, and C5 were used as standards for the quantitative analysis. Those compounds were dissolved in chloroform to obtain different concentrations (10, 25, $50 \mathrm{ppm})$. The quantification was performed using similar GC conditions between the standards and samples. The retention time and areas of the standards and samples were compared to obtain standard curves $\left(r^{2}>0.9\right)$. The content value of quantified compounds was expressed in milligrams per gram of dry weight (mg/g DW).

\section{ESI/MS Analysis}

In ESI/MS analysis, the chemicals were solubilized in chloroform-d $\left(\mathrm{CDCl}_{3}\right)$ to obtain a concentration of $50 \mu \mathrm{g} / \mathrm{mL}$. All measurements were conducted on mass spectrometer with electrospray ion source. Negative/positive ion mode was used with a capillary temperature of $140{ }^{\circ} \mathrm{C}\left(120^{\circ} \mathrm{C}\right.$ for S2) and a spray voltage of $3.0 \mathrm{kV}(2.7 \mathrm{kV}$ for S2). The measurements were performed in the positive mode with an ion spray voltage of $3000 \mathrm{~V}$ and a capillary temperature of $350{ }^{\circ} \mathrm{C}$. Data were collected in full scan mode within the range 280 to $1000 \mathrm{~m} / \mathrm{z}$.

\section{NMR Analysis}

The samples were dissolved in chloroform-d $\left(\mathrm{CDCl}_{3}\right)$. The spectroscopic data were compared with those of literature to identify the structure of isolated organic compounds.

\subsection{Inhibitory Activity of Isolated Compounds in Bioassays}

Different dilutions $(5,10,50,100,250$ and $500 \mu \mathrm{g} / \mathrm{mL})$ of isolated compounds and their mixture distilled in $\mathrm{MeOH}$ were prepared to check the germination rate of $R$. sativus seeds. All test plant seeds were soaked in distilled water to remove the empty and undeveloped seeds. Each five remaining seeds were sown in each 12 well-plate ( $22.1 \mathrm{~mm}$ diameter $\times 35 \mathrm{~mm}$ height) with filter paper moistened by $100 \mathrm{~mL}$ test compound solvent in triplicate. Methanol was used as the controls. After that, all test plates were kept for 5 days in a growth chamber set at $25{ }^{\circ} \mathrm{C} \pm 2{ }^{\circ} \mathrm{C}$ with $8 / 16 \mathrm{~h}$ day/night cycle. The root lengths and shoot heights were measured and the concentration reducing $50 \%$ of seedling growth was calculated $\left(\mathrm{IC}_{50}\right)$.

\subsection{Statistical Analysis}

The statistical analyses were implemented by Minitab ${ }^{\circledR} 16.2 .3$ (copyright (C) 2012 Minitab Inc., Philadelphia, PA, USA). Mean and standard deviation values were evaluated using one-way ANOVA. Turkey's test was applied to compare significant differences between treatment, control and standard data various results at $p<0.05$.

\section{Conclusions}

The findings of this study revealed that $P$. methysticum roots contain a number of potent plant growth inhibitors. The use of combinations of hexane-ethyl acetate at 9:1 and 8:2 ratios in column chromatography resulted in the successful isolation and purification of two flavanones $\mathbf{C 1}$ and $\mathbf{C 2}$, of which the $\mathbf{C} 2$ (matteucinol) was detected for the first time in P. methysticum root and kavalactones C3-C6, of which the C2 (matteucinol) was the first time detected in P. methysticum root. The ethyl acetate extract showed the strongest inhibitory level as compared with hexane, chloroform, acetone and water ones. The isolated flavanones $\mathbf{C 1}$ and $\mathbf{C} 2$ and kavalactones (C3-C6) showed reversed different levels of activity on elongation of shoot and root of $S$. sativus, suggesting that they may possess distinct 
modes of action. This study established an efficacious extraction and purification protocol for the bioactive constituents, principally kavalactones and flavanones in P. methysticum roots, to aid effective exploitation of the potential use of this herbal plant for the development of natural herbicides as well as medicines and pharmaceutics.

Supplementary Materials: The following are available online, Figures S1-S24 are provided.

Author Contributions: T.M.V. and T.D.X. conceived and designed the experiments. T.M.V. and T.N.M. conducted the experiments, analysed the data and wrote the manuscripts. T.D.X. and N.V.Q. gave advice and revised the manuscript. All authors approved the final version of the manuscript.

Funding: This research received no external funding.

Acknowledgments: We thank Phung Thi Tuyen for helpful advice to this research.

Conflicts of Interest: The authors declare no conflict of interest.

\section{References}

1. Rice, E.L. Allelopathy, 2nd ed.; Academic Press Inc.: Orlando, FL, USA, 1984; p. 422. ISBN 0125870558.

2. Khanh, T.D.; Chung, I.M.; Xuan, T.D.; Tawata, S. The exploitation of crop allelopathy in sustainable agricultural production. J. Agron. Crop Sci. 2005, 191, 172-184. [CrossRef]

3. Singh, Y.N. Kava: An overview. J. Ethnopharmacol. 1992, 37, 13-45. [CrossRef]

4. Blumenthal, M. Kava safety questioned due to case reports of liver toxicity. Herbal Gram 2002, 55, 26-32.

5. Meyer, H.J. Pharmacology of kava. In Ethnopharmacologic Search for Psychoactive Drugs, 2nd ed.; Efron, D.H., Holmstedt, B., Kline, N.S., Eds.; Raven Press: New York, NY, USA, 1979; ISBN 9780300052138.

6. Lebot, V.; Merlin, M.; Lindstrom, L. Kava: The Pacific Drug; Yale University Press: New Haven, CT, USA, 1992; ISBN-10 0300052138, ISBN-13 978-0300052138.

7. Hong, N.H.; Xuan, T.D.; Tsuzuki, E.; Matsuo, M.; Ogushi, Y. Evaluation of the allelopathic potential of kava (Piper methysticum L.) for weed control in rice (Oryza sativa). Weed Biol. Manag. 2002, 2, 143-147. [CrossRef]

8. Xuan, T.D.; Eiji, T.; Hiroyuki, T.; Mitsuhiro, M.; Khanh, T.D. Identification of potential allelochemicals from kava (Piper methysticum L.) root. Allelopath. J. 2003, 12, 197-203.

9. Xuan, T.D.; Elzaawely, A.A.; Fukuta, M.; Tawata, S. Herbicidal and fungicidal activities of lactones in Kava (Piper methysticum). J. Agric. Food Chem. 2006, 54, 720-725. [CrossRef] [PubMed]

10. Xuan, T.D.; Tawata, S.; Khanh, T.D.; Chung, I.M. Decomposition of allelopathic plants in soil. J. Agron. Crop Sci. 2005, 191, 162-171. [CrossRef]

11. Xuan, T.D.; Fukuta, M.; Wei, A.C.; Elzaawely, A.A.; Khanh, T.D.; Tawata, S. Efficacy of extracting solvents to chemical components of kava (Piper methysticum) roots. J. Nat. Med. 2008, 62, 188-194. [CrossRef] [PubMed]

12. Junior, R.W.A.; Gomes, D.B.; Zanchet, B.; Schönell, A.P.; Diel, K.A.; Banzato, T.P.; Ruizc, A.L.T.G.; Carvalhoc, J.E.; Neppel, A. Antiproliferative effects of pinostrobin and 5,6-dehydrokavain isolated from leaves of Alpinia zerumbet. Rev. Bras. Farmacogn. 2017, 27, 592-598. [CrossRef]

13. Whitton, P.A.; Lau, A.; Salisbury, A.; Whitehouse, J.; Evans, C.S. Kava lactones and the kava-kava controversy. Phytochemistry 2003, 64, 673-679. [CrossRef]

14. Dragul, K.; Yoshida, W.Y.; Tang, C. Piperidine alkaloids from Piper methysticum. Phytochemistry 2003, 63, 193-198. [CrossRef]

15. Wu, D.; Yu, L.; Nair, M.G.; DeWitt, D.L.; Ramsewak, R.S. Cyclooxygenase enzyme inhibitory compounds with antioxidant activities from Piper methysticum (kava kava) roots. Phytomedicine 2002, 9, 41-47. [CrossRef] [PubMed]

16. Bilia, A.R.; Bergonzi, M.C.; Lazari, D.; Vinceiri, F.F. Characterization of commercial kava-kava herbal drug and herbal drug preparations by means of nuclear magnetic resonance spectroscopy. J. Agric. Food Chem. 2002, 50, 5016-5025. [CrossRef] [PubMed]

17. Meissner, O.; Haberlein, H. HPLC analysis of flavokavins and kavapyrones from Piper methysticum Forst. J. Chromatogr. B 2005, 826, 46-49. [CrossRef] [PubMed]

18. Asaduzzaman, M.D.; Islam, M.M.; Sultana, S. Allelopathy and allelochemicals in rice weed management. Bangladesh Res. Publ. J. 2010, 4, 1-14.

19. Seigler, D.S. Chemistry and mechanisms of allelopathic interactions. Agron. J. 1996, 88, 876-885. [CrossRef] 
20. Soltys, D.; Krasuska, U.; Bogatek, R.; Gniazdowska, A. Allelochemicals as bioherbicides-Present and perspectives. In Herbicides-Current Research and Case Studies in Use; Price, A.J., Kelton, J.A., Eds.; Intech: Rijeka, Croatia, 2013; ISBN 978-953-51-1112-2.

21. Andriana, Y.; Xuan, T.D.; Quan, N.V.; Quy, T.N. Allelopathic potential of Tridax procumbens L. on radish and identification of allelochemicals. Allelopathy J. 2018, 43, 223-237. [CrossRef]

22. Altemimi, A.; Lakhssassi, N.; Baharlouei, A.; Watson, D.G.; Lightfoot, D.A. Phytochemicals: Extraction, Isolation, and Identification of Bioactive Compounds from Plant Extracts. Plants 2017, 6, 42. [CrossRef] [PubMed]

23. Singh, Y.N.; Blumenthal, M. Kava: An overview. Herbal Gram 1997, 39, 34-55. [CrossRef]

24. Rowe, A.; Zhang, L.Y.; Ramzan, I. Toxicokinetics of kava. Adv. Pharmacol. Sci. 2010, 2011, 1-6. [CrossRef] [PubMed]

25. Teschke, R.; Lebot, V. Proposal for a kava quality standardization code. Food Chem. Toxicol. 2011, 49, 2503-2516. [CrossRef] [PubMed]

26. Bhat, Z.S.; Rather, M.A.; Maqbool, M.; Lah, H.U.; Yousuf, S.K.; Ahmad, Z. $\alpha$-pyrones: Small molecules with versatile structural diversity reflected in multiple pharmacological activities-an update. Biomed. Pharmacother. 2017, 91, 265-277. [CrossRef] [PubMed]

27. Siméoni, P.; Lebot, V. Identification of factors determining kavalactone content and chemotype in kava (Piper methysticum Forst. f.). Biochem. Syst. Ecol. 2002, 30, 413-424. [CrossRef]

28. Li, B.B.; Smith, B.; Hossain, M.d.M. Extraction of phenoloics from citrus peels I. Solvent extraction method. Sep. Purif. Technol. 2006, 48, 182-188. [CrossRef]

29. Vera, N.; Solorzano, E.; Ordoñez, R.; Maldonado, L.; Bedascarrasbure, E.; Isla, M.I. Chemical composition of Argentinean propolis collected in extreme regions and its relation with antimicrobial and antioxidant activities. Nat. Prod. Commun. 2011, 6, 823-827. [PubMed]

30. Wan, W.M.N.H.S.; Ahmad, F.; Yen, K.H. Essential oils, phytochemicals and bioactivities of Piper caninum Blume. In Natural Heterocycles: Extraction and Biological Activity; Ameta, K.L., Ed.; Nova Science Publishers Inc.: London, UK, 2015; ISBN 978-163-463-462-5.

31. Mangoyi, R.; Midiwo, J.; Mukanganyama, S. Isolation and characterization of an antifungal compound 5-hydroxy-7,4'-dimethoxyflavone from Combretum zeyheri. BMC Complement. Altern. Med. 2015, 15. [CrossRef] [PubMed]

32. Mierziak, J.; Kostyn, K.; Kulma, A. Flavonoids as important molecules of plant interactions with the environment. Molecules 2014, 19, 16240-16265. [CrossRef] [PubMed]

33. Rouse, J. Kava: A South Pacific herb for anxiety, tension and insomnia. Clin. Nutr. Insights 1998, 96, 3900-3905.

34. Teschke, R.; Sarris, J.; Schweitzer, I. Kava hepatotoxicity in traditional and modern use: The presumed Pacific kava paradox hypothesis revisited. Br. J. Clin. Pharmacol. 2012, 73, 170-174. [CrossRef] [PubMed]

35. Rowe, A.; Ramzan, I. Are mould hepatotoxins responsible for kavahepatotoxicity? Phytother. Res. 2012, 26, 1768-1770. [CrossRef] [PubMed]

36. Grace, R.F. Kava drinking in Vanuatu-A hospital based survey. Pac. Health Dialog. 2003, 10, 41-44. [PubMed]

37. Zhou, P.; Gross, S.; Liu, J.H.; Yu, B.Y.; Feng, L.L.; Nolta, J.; Piwnica-Worms, D.; Qiu, S.X. Flavokawain B, the hepatotoxic constituent from kava root, induces GSH-sensitive oxidative stress through modulation of IKK/NF-KB and MAPK signaling pathways. FASEB J. 2010, 24, 4722-4732. [CrossRef] [PubMed]

38. Singh, Y.N.; Devkota, A.K. Aqueous kava extracts do not affect liver function tests in rats. Planta Med. 2003, 69, 496-499. [PubMed]

39. DiSilvestro, R.A.; Zhang, W.; DiSilvestro, D.J. Kava feeding in rats does not cause liver injury nor enhance galactosamine-induced hepatitis. Food Chem. Toxicol. 2007, 45, 1293-1300. [CrossRef] [PubMed]

40. Xuan, T.D.; Teschke, R. Dihydro-5,6-dehydrokavain (DDK) from Alpinia zerumbet: Its isolation, synthesis, and characterization. Molecules 2015, 20, 16306-16319. [CrossRef] [PubMed]

41. Elzaawely, A.A.; Xuan, T.D.; Tawata, S. Changes in essential oils, kava pyrones and total phenolics of Alpinia zerumbet (Pers.) B.L. Burtt. \& R.M. Sm. leaves exposed to copper sulphate. Environ. Exp. Bot. 2007, 59, 347-353.

42. Elzaawely, A.A.; Xuan, T.D.; Tawata, S. Essential oils, kava pyrones and phenolic compounds from leaves and rhizomes of Alpinia zerumbet (Pers.) B.L. Burtt. \& R.M. Sm. and their antioxidant activity. Food Chem. 2007, 103, 486-494. 
43. Tawata, S.; Fukuta, M.; Xuan, T.D.; Deba, F. Total utilization of tropical plants Leucaena leucocephala and Alpinia zerumbet. J. Pest. Sci. 2008, 33, 40-43. [CrossRef]

44. Teschke, R.; Xuan, T.D. Viewpoint: A contributory role of shell ginger (Alpinia zerumbet) for human longevity in Okinawa, Japan? Nutrients 2018, 10, 166. [CrossRef] [PubMed]

45. Suyatno, S.; Syarief, S.H.; Hidajati, N.; Rinningsih, R.; Tori, M.; Shimizu, K. Phenolic compounds isolated from the fern Chingia sakayensis (Zeiller). J. ILMU DASAR 2009, 10, 22-29.

46. Wongsa, N.; Kanokmedhakul, K.; Boonmak, J.; Youngme, S.; Kanokmedhakul, S. Bicyclic lactones and racemic mixtures of dimeric styrylpyrones from the leaves of Miliusa velutina. RSC Adv. 2017, 7, 25285-25297. [CrossRef]

Sample Availability: Samples of the compounds are available from the authors.

(C) 2018 by the authors. Licensee MDPI, Basel, Switzerland. This article is an open access article distributed under the terms and conditions of the Creative Commons Attribution (CC BY) license (http://creativecommons.org/licenses/by/4.0/). 